\title{
South Africa: Political Economy or Virtual Economics?
}

\section{L Truu}

Department of Economics, University of Pretoria

\section{ABSTRACT}

In 1994 South Africa was politically transformed from an oligarchy into a democracy. How has this momentous change affected the framework of economic policy? This paper approaches the question via the virulent unemployment that is South Africa's most serious economic problem today. The apparent answer gives great cause for concern: South Africa's policy-makers seem about to leave the real world of political economy to enter the illusory world of virtual economics instead.

“... a little fact will sustain a lot of illusion ... The lie stands most securely on a pin-point of truth." Eric Ambler, Judgment on Deltchev (1951).

\section{INTRODUCTION}

As in the past, the expression "political economy" has several shades of meaning today. It is, for example, much used in the context of the large-scale transition from (real) socialism to (mixed) capitalism, particularly in central and eastem Europe, where it usually refers to a more or less systematic interaction of political and economic variables. Thus, the abolition of communism-socialism was a political sea change that is totally reshaping basic economic institutions like property rights, money and prices. South Africa, too, experienced a decisive political break with the past in April 1994, when it changed from an oligarchic to a democratic form of government. It would be most naïve to think that such political transformation would have no major economic consequences. This means that there is a good reason to approach the political economy of South Africa today as a "unified subject", as Professor Avinash Dixit (TE, Sept. $201997 ; 8$ ) has expressed it. The problem at the core of economic policy in present-day South Africa has 
been concisely put by the American development economist R. Stephen Brent (Foreign Affairs, March/April 1996: 117) in the following words:

The challenge for the government is to keep the focus on long-term growth but provide enough benefits to the majority population along the way that pelitical consensus can be maintained and moral commitments protected.

It would be difficult for anyone to disagree with this general diagnosis.

The term "virtual economics" which also appears in the title of this paper, has just been invented by the author. This does, however, not represent a claim to originality, for the wording is obviously a variation on the name "virtual reality", which may be defined as follows: "Virtual reality ... creates the illusion of being immersed in an artificial world, or being present in a remote location in the physical world" (Mondo 2000, $1993: 252$ ). The device is by no means new to economics. Its all-time champion was the French socialist Charles Fourier (17721837), who abhorred industrialism and advocated a retum to the land. The hub of his envisaged rural economy was the Phalanstère, where a worker "would be employed almost exclusively in looking after his garden, just like Adam was before the Fall and Candide after his misfortunes" (Gide \& Rist, $1917: 242$ ). This did not amount to a purely abstract notion; the Phalanstere was actually tried out in the United States - and proved to be a complete failure. Karl Marx contemptuously dismissed this kind of socialism as unscientific and utopian, compared to his own doctrine of "scientific socialism".

How do these rival approaches (political economy vs virtual economics) relate to the above-mentioned problem at the core of South African economic policy? Faced with a comparably thorny issue, Joan Robinson (1962:1) recalled the counsel of The Great Boyg in Ibsen's Peer Gynt: "Backward or foreward, it's just as far. Out or in, the way's as narrow ... Go round about, go round about." So shall we, though remaining in the broad field of labour economics.

The great majority of economics students during the 1950 s and 1960 s were no doubt told by their instructors that the problem of unemployment had been solved for good by Keynesian fiscal policy. During approximately the first two decades after the second world war, the objective of full employment did in fact enjoy top priority in the market related economies. This, however, also meant an uninterrupted period of rising prices, as a result of which inflation came to be seen as the typical condition of the economy. In other words, the public lost its sense of 
money illusion, or faith in price stability, and came to expect that the past experience of inflation would continue in the future as well.

\section{RETURN OF UNEMPLOYMENT}

In terms of the traditional Philips Curve model, it had been possible to "buy" more employment at the cost of more inflation, both in the short and the long term. With the establishment of inflationary expectations, however, this trade-off disappeared in the long term, and stubborn policy attempts to stimulate more employment would only cause more inflation without raising employment and output. The main reason for this is that government spending designed to increase economic activity, came to be neutralised by policy clashes and trade union action to maintain (or increase) real wages.

As a result of inflationary expectations, unemployment once more became a serious problem during the 1970 s. This, inter alia, led to a redefinition of the concept labour market equilibrium. The latter no longer signified an optimal situation, implying a state of full employment. Instead, equilibrium in the labour market was said to exist when trade union determined wage rates were equal to the rates that business firms considered economically feasible, which would then coexist with the economy's natural rate of unemployment (Stiglitz, 1977:4). To make the point that this should not be taken to mean a normal or desirable state of affairs, economists replaced the last-mentioned term by the rather cumbersome phrase "nonaccelerating-inflation rate of unemployment" (NAIRU). This is the rate of unemployment, other things being equal, to which the economy tends to return in the long run.

NAIRU increased world-wide during the 1970 s and the first half of the 1980s, when the OPEC cartel practically held the oil importing nations to ransom. This ill-considered policy eventually caused an oil glut on the world market, and thus boomeranged on its author when the price of oil was more than halved in 1985-86. As a result, both the actual and the expected rate of inflation fell, which served to reverse the rising trend of NAIRU in the economically developed countries. South Africa, however, did not share in this positive turn of events. Although the international oil price expressed in US dollars fell precipitately, the dollar value of the rand fell even more at the time. Consequently the price of oil in terms of the rand actually rose in South Africa, and inflationary expectations continued as before. 
Against the background of rapid technological progress, particularly the information revolution, NAIRU has again recently declined in the United States (Gordon, 1997 : 29-30), though not in Europe (Blanchard \& Katz, 1997 : 66-7). Unemployment in South Africa has by now become the country's most serious economic problem. According to available estimates, the long-term increase in unemployment relative to the labour force, has been alarming to say the least : $8 \%$ in $1960,12 \%$ in $1980,19 \%$ in 1991 and $29 \%$ in 1995 (FM, July $41997: 35$ ). Whatever the actual size of South Africa's NAIRU may be, it has certainly grown a great deal over the years.

From time to time, someone makes the point that "Keynes taught us how to conquer unemployment" (in excess of its so-called frictional level of, say, 2 or 3 per cent). This would mean a deliberate policy of deficit spending by the government. In present-day conditions, however, such a policy option is a nonstarter (Kapstein, Krugman \& Lawrence, 1996 : 16-37, 164-73). Keynesian-type deficit spending was originally designed to eliminate cyclical unemployment caused by deficient aggregate demand. But this is not at all the same thing as the structural (or supply side) unemployment that has entrenched itself today. Far from reducing unemployment, large budget deficits would serve to rekindle inflation where it has been extinguished, or cause inflation to accelerate in countries where it has slowed down (e.g. South Africa).

The essential nature of unemployment today is shown in Figure 1, which depicts an imaginary labour market (where frictional unemployment is not taken into account).

Figure 1: The labour market

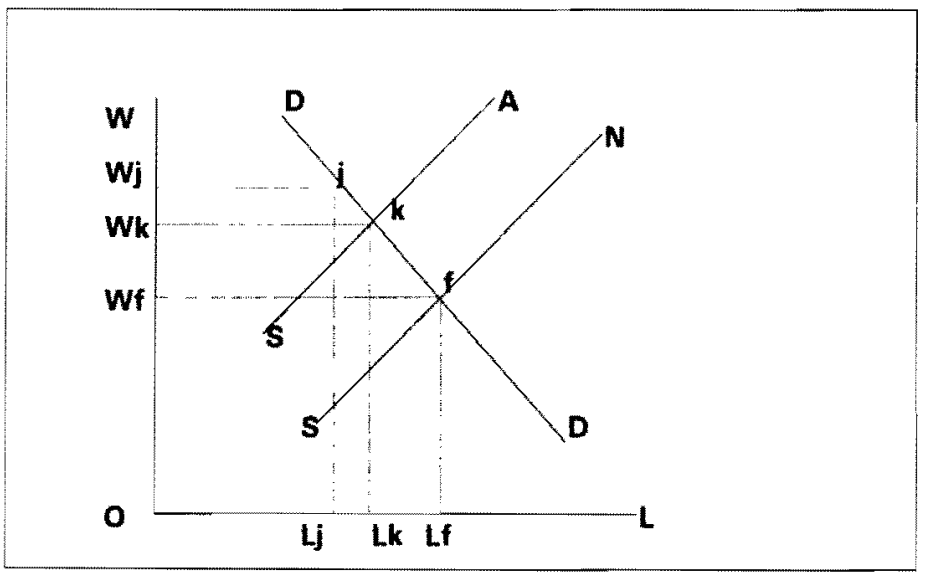


There is only one demand curve for labour, DD, but two supply curves marked SN and SA, where the former represents the notional (or potential) and the latter the actual (or effective) supply of labour. The split in labour supply means that some workers are adequately qualified for the jobs available in the market, others not. Alternatively put, the composition of labour demand and labour supply are not perfectly matched. Notional equilibrium with full employment would be at point $\mathbf{f}$ (wage rate $\mathbf{W f}$, employment $\mathbf{L f}$ ), but actual equilibrium occurs at point $\mathbf{k}$, where the demand for labour is equal to its actual or effective supply. Thus, at wage rate Wk the number of workers employed (those with the right skills) are represented by Lk. This would then amount to equilibrium of a sort in the labour market, coexisting with structural unemployment (where demand and supply fail to mesh) equal to LkLf. Unemployment may be aggravated by trade union behaviour. Assume that a trade union demands, and gets, a wage rate equal to $\mathbf{W j}$. Employers would then respond by reducing their labour input to $\mathbf{L j}$. Provided that the trade union members keep their jobs, a new state of equilibrium would then coexist at point $\mathbf{j}$ with $\mathbf{L j L f}$ unemployment, due partly to job-worker mismatch and partly to trade union pressure. The economy's natural rate of unemployment (NAIRU) would then be equal to LjLf/OLf per cent. This imaginary labour market example is in fact not far removed from what is happening in the formal sector of the South African economy today.

This discussion has important macroeconomic implications, both theoretical and practical. The natural rate of unemployment is common to both the labour market and modern Phillips Curve analysis. Given inflationary expectations, there is no permanent trade-off between inflation and unemployment: the long-term Phillips Curve is vertical at NAIRU level. The Phillips Curve is not a special case, separate from the rest of macroeconomics. It is in fact directly related to the aggregate demand - aggregate supply (AD-AS) model, where the long-term AS-schedule is also vertical (Truu \& Contagiannis, $1996: 221-25$ ). The position of the long-term Phillips Curve is determined by NAIRU, that of the AS-schedule by its reciprocal: the total labour force minus natural unemployment. Policies to train (or retrain) workers and curb trade union power, would therefore at the same time serve to increase effective labour supply, the economy's productive capacity and aggregate supply of final output. Appropriate training would make more workers employable in an increasingly sophisticated economy, and less trade union militancy would be generally 1997 conducive to more labour-intensive production methods. 


\section{LONG-TERM ECONOMIC GROWTH}

The classic method how productive capacity expands over time, is by means of economic growth. Samuelson and Nordhaus boldly state in their best-selling textbook: "Economic growth is the single most important factor in the economic success of nations in the long run." (Samuelson \& Nordhaus, 1992:546). Although aggregate demand and aggregate supply jointly determine the economic growth rate, aggregate supply is the greater force behind the growth process. Expressed in the most general terms, the economy's output of final goods and services (i.e. its real income) results from both quantitative and qualitative causes, namely, the physical inputs of labour and capital as well as their productivity. With regard to the labour force, long-term economic growth holds the promise of more jobs and rising per capita output, real wages and living standards. The World Bank affirms tout court: "Economic growth is good for workers." (WDR, 1995:3). The respective weights of the three above-mentioned growth factors do vary according to time and place, but a steady improvement in productivity (or technological innovation) is the crucial determinant of economic growth in the long term (Bacon \& Eltis, 1978:35).

Both the meaning and measurement of productivity tend to be poorly understood, but here it is possible to note only two popular misconceptions, more or less midway between a half-truth and complete error. First, productivity is measured by expressing output as a ratio to a selected input, e.g., labour productivity is equal to output divided by labour input. It is frequently asserted that if a given reduction in labour input causes final output to fall less than proportionately, then labour productivity would have risen. This arithmetical truism is, however, not economically meaningful. In economics, productivity is deemed to increase if a given quantity of input(s) produces more output than before. Thus labour productivity would be raised by more capital per worker, enhanced labour skills and improved production technology in general.

A particularly hardy fiction is represented by the claim that higher productivity (or technological innovation) destroys jobs and perpetuates unemployment. Paul Krugman has called its current version the doctrine of global glut, or "the view that capitalism is too productive for its own good" and "there simply is not enough work to go around ... as productivity rises" (Krugman, $1997: 79,82$ ). While it is true that technological innovation destroys old jobs, it also serves to create new jobs. The process is in fact known as "creative destruction", today generally represented by the transformation of secondary (manufacturing) into tertiary (service) jobs. However, the fact remains that some societies (e.g. USA) are 
managing the transformation rather better than others (e.g. western Europe). While the debate continues, the reason most frequently given for their disparate performance, is that European labour markets are less flexible than their American counterparts.

An important development has been the new growth theory pioneered by Paul Romer (Romer, 1986 : 1002-37). According to this approach, knowledge is classified as a source of economic growth, just like raw labour and physical capital. The growth of knowledge results from investment in human capital, based on the same logic and incentives that motivate investment in physical capital assets. The new growth theory has, inter alia, toppled the old platitude that less affluent countries typically have too little physical capital, instead, the main problem is that they invest too little in human capital.

Romer's theory has been followed by a remarkable upsurge of empirical research, that overwhelmingly confirms the positive relation between human capital and real income growth. The locus classicus of these studies is a paper by Robert Barro (1991 : 408-43), based on cross-section data for 98 countries (including South Africa) over the period $1960-85$, which yielded the following conclusion :

...the growth rate of real per capita GDP is positively related to initial human capital...Countries with higher human capital also have lower fertility rates and higher ratios of physical investment to GDP. Growth is inversely related to the share of government consumption in GDP, but insignificantly related to the share of public investment. Growth rates are positively related to measures of political stability and inversely related to a proxy for market distortions.

Potentially significant causes of economic growth have therefore come to encompass several factors other than quantitative labour and capital inputs, lumping the rest together under the "residual". Moreover, never before has the non-specialist press shown so much interest in scientific growth studies as during the past half-dozen years, or so (see e.g. The Economist (London) : Jan. 4 1992, pp. 17-20; Jan. 11 1992, pp. 19-21; May 25 1996, pp. 23-29; June 29 1996, pp. 23-25; June 14 1997, pp. 19-24).

We may also note the gist of a major research project by Jeffrey Sachs and associates at Harvard University (Sachs, 1997 : 19-24). International patterns of economic growth during the research period (1965-90) were found to depend crucially on four sets of factors: initial conditions, population trends, physical 
geography and government policy. The initial conditions include per capita output and human capital endowment, the first-mentioned varying inversely and the lastmentioned directly with the per capita economic growth rate. More gradual population growth (ideally the difference between declining fertility and low mortality) would reduce economic dependency and raise the average income level. Geographical properties likely to impede growth, are adverse climate, poor soil and landlocked location. Such disadvantage may, however, be offset by favourable official policy, for example, consistent market orientation and liberalisation, openness to foreign trade and investment, private instead of state ownership, protection of private property rights, low tax rates, fiscal saving, rule of law and honest administration. Not surprisingly, Sachs arrives at the following conclusion: "Global capitalism is surely the most promising institutional arrangement for world-wide prosperity that history has ever seen." This seems the essence of what the term globalisation means today. The combination of globalisation and information technology has in turn been given the name of "The New Economy" so far restricted to the USA (BW, Nov. 17 1997: 48-50).

Increased productivity induces new investment in human and physical capital, and thus promotes economic growth. In a study that covered 133 countries (including South Africa), Hall and Jones $(1996: 33)$ found that the level of a country's productivity depends on the following factors, in descending order of importance : institutions that favour production over "diversion" (e.g. theft, corruption, expropriation, high taxes), openness to international trade, private ownership, knowledge of an international language (e.g. Arabic, Chinese, English), and a temperate climate. The causes of productivity are therefore quite similar to the causes of growth.

\section{LABOUR CONDITIONS IN SOUTH AFRICA}

Seeing that high unemployment and deficient job opportunities reside at the core of South Africa's labour problems, despite recently positive economic growth, the following comment on labour conditions in Europe (Siebert, 1997:53) may serve as a starting point for South Africa too:

The institutional phenomena described in this paper have led to a dual labor market in most European countries. There is a sizable section of the labor force for which the labour market does not function anymore. The combination of intensified competition in a global economy and of labor-saving technical progress requires flexibility in wages, but 
this flexibility is prevented by institutional conditions. Once created, unemployment is reinforced by ratchet effects; it becomes more and more difficult to find employment again when one has been out of employment for a while. The unemployed lose qualifications relative to the employed; in severe cases, they may lose their social competence altogether. Unemployment can easily become persistent, and to overcome rising unemployment in a self-enforcing trap, it takes a comprehensive push of institutional change. Indeed, the specter of unemployment that is haunting Europe will not be exorcised unless governments are prepared to undertake major reforms of the institutional set-up of the labor market.

Examples of institutional labour market disincentives in Europe are said to include: attractive welfare, social security and unemployment payments; high levels of minimum wages; powerful trade unions; extensive regulations governing hours of work, business zones and leave conditions; payroll taxes; job protection laws; difficult and costly dismissal procedures, and so on. The term "Euro-sclerosis" has been invented to describe such an inefficient labour market. Shortage of investment capital may aggravate the predicament. Apart from less generous welfare benefits, all these disincentives, and more, have an even much greater negative effect on labour conditions in South Africa today. The policy of affirmative action is a particularly strong barrier to job creation in South Africa. The expression "jobless growth" has been coined for this disconsolate situation (TE, Sept. 27 1997:52).

Deep-seated labour problems have been present throughout South Africa's economic history. The major problem areas during the twentieth century have been an abundance of unskilled and a relative shortage of skilled workers, the migratory labour system, the economic colour bar and complex industrial relations (Wilson, 1972:1).

The descent into mass unemployment was, amongst others, foreshadowed by Professor Hobart Houghton when he wrote in the 1960s:

If South Africa is to expand manufacturing industries, it is essential to adopt the most modern processes. Attempts to compete with automated industry by using labour-intensive processes seem doomed to failure ... Moreover in a labour force lacking a high degree of manual dexterity and craftsmanship, automation has been found to improve quality and reduce cost ... Automation in industry, however, renders most unskilled labour redundant (1967:165). 
Having failed to meet the (above) challenge once raised by automation, the South African economy is today again powerless in reconciling the sectoral shift from manufacturing to services with growing job opportunities. The fact that South Africa's labour force has proved unable to meet the needs of a progressively more sophisticated economy, is no less than a national failure. It is also the underlying, long-term cause of today's unemployment debacle, the essence of which is captured by the index numbers $(1990=100)$ below.

\begin{tabular}{|l|l|l|l|l|l|l|l|l|}
\hline Year & $\mathbf{1 9 9 0}$ & $\mathbf{1 9 9 1}$ & $\mathbf{1 9 9 2}$ & $\mathbf{1 9 9 3}$ & $\mathbf{1 9 9 4}$ & $\mathbf{1 9 9 5}$ & $\mathbf{1 9 9 6}$ & $\mathbf{1 9 9 7}$ \\
\hline $\mathbf{Q}$ & 100.0 & 99.0 & 96.8 & 98.1 & 100.8 & 104.1 & 107.4 & 109.2 \\
\hline $\mathbf{L}$ & 100.0 & 98.3 & 96.3 & 94.3 & 93.7 & 94.4 & 93.3 & $91.9^{\star}$ \\
\hline
\end{tabular}

Note: $\quad Q=$ Real GDP, $L=$ Non-agricultural employment.

$$
\text { * Jan. - Sept. }
$$

Source: $\quad$ SARB, Quarterly Bulletin (various issues).

Not only has economic growth been erratic and thus an unreliable source of employment during the 1990s so far, but even when growth was positive, employment has still fallen largely on account of "unemployable" labour.

Employment growth has also been held back by a long-term process of capital deepening, for example, the capital-output ratio in the South African economy rose from 2.22 in 1960-64 to 3.32 in 1993-97. This has been associated with sharp increases in wages and other labour costs, like those caused by strikes, stayaways and the so-called institutional disincentives mentioned at the beginning of this section (CEAS, 1993:42-3). Briefly put, labour problems have caused business firms to adopt excessively capital-intensive, and hence economically wasteful, production methods.

The topic of trade union activity inevitably takes one into the realm of so-called political economy, in other words, the economic consequences of political behaviour. The political power enjoyed by Cosatu, South Africa's largest and most influential trade union federation, is comparable only to the Solidarity movement in Poland. Cosatu is much more than a conventional trade union entity, together with the African National Congress and the South African Communist Party it actually governs the country. Cosatu is therefore not really constrained by collective bargaining in the labour market or the country's economic state of health. If need be, its demands are simply enforced by government, in other words, Cosatu's will 
then becomes the law of the land. One example of this is the soon to-be-passed Basic Conditions of Employment Act, with a potentially "disastrous effect on growth and job creation" and "the triumph of politics over economic reality" (STBT, Nov. 9 1997). Other examples of recent labour legislation - already passed or awaiting ratification - have a similarly negative effect on employment in South Africa.

Cosatu's political lineage is of the revolutionary Marxist-Leninist kind (Truu, 1997:47), moreover, "the government is still clinging to its belief that ideology did not entirely succumb to market forces with the collapse of the Soviet Union" (FTS, Sept. $191997: x x v)$. To vilify the business sector, left-wing spokesmen even trot out what is probably the biggest Marxian fallacy of all, the tired old base-superstructure theory that in pre-1994 South Africa too, government was the servant of capital $(P N$, Nov. 13 1997; $B D$, Nov. 14 1997:1, 15). Bombarding private enterprise with threats and abuse, government and trade union representatives seemingly overlook the fact that such poisonous atmosphere is least of all conducive to investment and job creation. Also, given South Africa's high incidence of serious crime and its "burgeoning corruption in the government" (TEIU, South Africa, 3rd quarter 1997:7), only the less risk-averse entrepreneurs seem prepared to invest their capital in the country. As if this were not enough, ordinary (white) households have also been stridently berated at top government level. Even the foreign press was moved to describe such rhetoric as "paranoid" and "dated Marxist theology" (PN, Dec. 19 1997:8).

Although South Africa's inadequate stock of human capital was called a national failure above, this does not mean complete failure - in the sense of being incapable of future progress. Even people who live in a generally adverse socioeconomic environment, show positive evidence of meaningful development potential. For example, some 17 per cent of the South African labour force is occupied in so-called informal economic activity, instead of being literally unemployed. It would be difficult, perhaps impossible, to find a more urgent economic challenge to South Africa than the empowerment of its labour force. The same thought was expressed by the President of the World Bank James Wolfensohn, when he said that too many people have been excluded from gainful employment, choosing the title The Challenge of Inclusion for his 1997 annual address to the Bank's governors. 


\section{INTERNATIONAL OPINION}

\section{Sense from Bretton Woods}

At the beginning of 1992 when the new political dispensation was already in the offing, the International Monetary Fund (IMF) published an Occasional Paper with the title Economic Policy for a New South Africa, edited by Desmond Lachman and Kenneth Bercuson. This slender volume is noted for its common sense and unvarnished realism. For example:

The main conclusion to be drawn is that poverty in South Africa is so severe that redistribution policies, which alone will not be adequate to counter it, must be supported by policies designed to place the economy on a higher growth path. Only then should the economy be expected to generate the resources necessary to satisfy the needs of the least privileged sectors on a sustained basis (p. 1).

This is, of course, the tested distribution-through-growth formula, which South Africa's policy-makers ignore at the peril of the national economy. Although economic growth and income redistribution are quite compatible in the long term, it is vital to get the sequence of events right in the short term. If initial priority is given to rapid growth, then greater equity has usually followed in due course. In contrast, research findings also show that if the priorities are reversed, then neither growth nor equity, but decline and poverty are more than likely to follow (Truu, 1992:291).

The IMF study goes on to say that a significantly improved growth performance is, in turn, conditional on the achievement of higher rates of domestic saving and investment, the reversal of declining productivity, a government budget surplus and moderate real wage growth to alleviate unemployment.

The authors of the International Labour Office publication discussed in the next section quite seriously claim that South Africans are manifestly under-taxed (their emphasis). On the other hand, the authors of the IMF study point out that the truth is more or less the opposite:

... the overall South African tax burden and its marginal rates cannot be judged to be low by international standards; indeed the tax burden on the white community appears to be relatively high even by industrial country standards. This would argue against raising tax 
rates in South Africa and running the risk of heightening disincentive effects (p.2).

This conclusion is still valid for South Africa today, though it would be only realistic to substitute for the expression "white community" the words "middleincome group". For it is government policy to tax all middle-class incomes and savings "til] the pips squeak". The IMF philosophy has, however, not met with total rejection in South Africa. The government's Growth, Employment and Redistribution (GEAR) strategy is precisely meant to "catapult the economy to the higher levels of growth, development and employment needed to provide a better life for all South Africans (GEAR, 1996:2)." Although the matter cannot be discussed here, the GEAR policy obviously calls for fiscal and monetary discipline, something which has - not surprisingly - been badly received by Cosatu and in other leftist circles.

The second Bretton Woods organisation, the World Bank, has also taken an interest in the South African economy, particularly its labour market and employment conditions. Three discussion papers on the subject have been written by Peter Fallon (1992), Fallon and de Silva (1994) and Fallon and Lucas (1997). The lastmentioned monograph bears the title South African Labour Markets : Adjustment and Inequalities, and restates the familiar employment-distribution relationship as follows :

There are two major policy aims: to reduce unemployment, and lessen labor market inequalities. Neither aim can be achieved by labor market policies alone. Sensible macroeconomic policies are needed to encourage labour-demanding growth, while the skills of much of the labor force must be improved considerably to support growth and lessen inequality. A competitive economic environment will also help, as discrimination tends to wither under such circumstances ( $\mathrm{p}$. 28).

The World Bank diagnosis of labour's role in the South African economy rests on deductive reasoning and statistical analysis, rather than preconceived notions and political correctness. For example: "Rising real product wages have a substantial dampening effect on the demand for Black workers" (p. 10) and "union activity depresses formal employment" (p. 18). If such findings are a rock of offence to left-wingers, those on the right may well be irked by the statement that "even after standardizing (for education and skills), wage differentials are still heavily 
determined by differences associated with labor market discrimination by race and gender" (p.14).

However, most of the World Bank's conclusions are (or should be) uncontroversial, for example: markets clear for skilled but not for unskilled work (p. ii); not just trade union determined wages, but excessively capital-intensive production methods, inadequate working skills and insufficient private investment serve to cause unemployment (p. 9); and "the probability of being unemployed is much lower for well-educated workers irrespective of racial group" (p. 13). The authors are no doubt right in suggesting that job creation would be promoted by the following policy approaches : more investment in human capital, more competitive markets (to avoid excessive wage increases), no policy intervention to raise wages, encouragement of the positive aspects of trade union activity, more labourintensive infrastructure and tripartite (state - labour - business) agreement on key issues (pp. 29-33). It is, however, most doubtful whether land reform in subsistence agriculture would be an effective way of creating jobs (pp. 3, 20, 28) in the - by third world standards - relatively sophisticated South African economy. Small and medium-sized business development seems a rather more likely bulwark against worklessness.

However, the kind of political economy discussed above cannot be taken for granted. If the relation between economics and politics is to be successful, then its main components must positively interact with each other over time, filling the roles of cause and effect by turns. The creation of employment opportunities, greater equality of income and wealth, and increased supply of social services are often said to be important policy objectives in South Africa. Such objectives can only be met consecutively, not all at once, and it is vital that the process should be started the right way - by an acceleration of economic growth. The combination of rapid growth and rising income would not only promote distributional equity but establish the budgetary base for increased social spending. Insofar as this is channeled into human capital formation (e.g. health care, education), the productivity of labour rises and the scope for employment growth is sustained.

But South Africa's policy-makers refuse to learn from experience. Attempts in the 1970 s to reduce the then existing wage gap autonomously, mainly caused inflation to accelerate $(A R, 1977: 15)$. In the new South Africa too, priority has been given to redistribution - at the wrong time. Fiscal policy so far has been to fleece middleincome taxpayers, perhaps because this is seen to incur little electoral risk. Neither has it benefited anyone economically, as the IMF warned. 


\section{Nonsense from Geneva}

The International Labour Office (ILO) in Geneva is noted for its social comment rather than economic analysis. In 1996 it published a Country Review by Guy Standing, John Sender and John Weeks with the title Restructuring the labour market: The South African Challenge.

This ILO Review was conceived and (partly) sponsored by the South African Department of Labour, and the responsible minister, Tito Mboweni, has contributed a foreword to it. The authors make the unassailable point that "a higher rate of economic growth is required to generate more employment and to reduce unemployment" (p. 38), but from the outset take leave of the real world to enter that of virtual economics instead. This is an illusory world where income redistribution and budget deficits cause the economy's productive capacity to grow (pp. 2, 31), where inflation is self-eliminating (p. 34) and macroeconomic stabilisation unnecessary (pp. 42-3), where state regulation is tantamount to market flexibility (p. 16), and where there are no unskilled workers, just unskilled jobs (p. 449 ), and high wages do not really have a dampening effect on employment ( $p$. 204).

The theoretical underpinnings of the system are almost equally bizarre. The authors generally favour a Keynesian-type approach, but when discussing economic growth they make use of a Cobb-Douglas production function where raw labour and physical capital provide the only input services. Technical progress is dismissed as "manna from heaven" (p. 199), while "endogenous" growth theory and "human capital" (arguably the most significant developments in modern growth analysis) are not only written between quotation marks but qualified by the (presumably derogatory) adjective so-called (p. 55) - after which they disappear from the scene. Or maybe not, for the 500-page Review has no index. This is a major disservice to readers, likely to be in for a long search should they wish to know the authors' perception (if any) of, say, the relation between population growth and labour supply or comparative informal sector employment elsewhere in Africa.

The authors say that their hypotheses are supported by "considerable international evidence" (p. 2), but it would be easy to name several authoritative studies that refute every one of their "heterodox" (p. 50) claims. However, as this would be rather tedious, only one example of such false premises is given here. The authors hold up the economies of South East Asia (the ASEAN countries) in the Review as a financial role model for South Africa, where monetary and fiscal discipline is 
seen to slow down economic growth unnecessarily (pp. 26, 51). Seldom has blind faith (or prejudice) been dealt a harder blow. The economic collapse that most ASEAN members suffered during 1997 was triggered precisely by their lax monetary and - to an extent - fiscal policies, against a background of pegged and overvalued exchange rates. In contrast, speculation against the rand was thwarted by "the fundamentally healthier state of macroeconomic management in South Africa" $(Q B$, Dec. 1997:18).

The authors keep building their virtual economy untrammeled by rules of logic: "Just because ... more of the non-poor have wage income than the poor, does not mean that increasing the number of low-wage jobs would reduce poverty and income inequality, although they may do so" (p. 225). This type of statement does not rule out any conceivable event from happening, thus, if low-wage jobs were in fact increased, then poverty (and income inequality) may in consequence increase, decrease or remain constant: obviously true, but useless knowledge. Policy questions raised by the authors themselves, are again dismissed for falling "outside our terms of reference" (p. 40). If so, why raise them in the first place?

The authors also tend to flounder whenever the conceptual difference between the short and long-term time periods comes up for discussion. In the event, their stock reaction seems to be that any short-term effects of relative prices are likely to be dominated by the long-term effects of economic growth (pp. 228-35). Incidentally, this might be a cryptic way of saying that neo-Keynesian economics is better than neo-classical economics. Or are these perhaps deeper waters? On the subject of labour market discrimination and disadvantage, the authors conclude: "The phenomena are systemic, the response must be systemic" (p.414). Now, this is a slogan that Marx might have coined, which could even lead one to suspect a Freudian slip when The Reconstruction and Development Programme is called The Reconstruction and Development Plan instead (p. 469). But that would be going too far; the ILO Review does have a leftist bias, however, without being cryptocommunist. The authors have, instead, produced what is today known as a politically correct document, likely to match the strongly dirigiste - also left-wing - bent of the South African government.

In his foreword, Mr Mboweni mentions two items that in a sense capture the essence of the book. First, thanks to informal economic activity, South Africa's effective rate of unemployment, though still alarmingly high, is less than often supposed - approximately 20 instead of 30 or even 50 per cent. (This might represent the pin-point of fact on which a large superstructure of fiction stands.) The second item is the recommended introduction of so-called Employment and 
Development Accords, which the authors proffer in place of conventional labour market arrangements. This is, of course, the epitome of virtual economics, and the kind of scenario bound to appeal to both the Department of Labour and its undisguisedly revolutionary alter ego Cosatu. But there is no comfort in this hocus-pocus for employment and growth in South Africa.

\section{CONCLUSION}

To summarise, unemployment in South Africa has two major causes: lack of appropriate working skills and a hostile market environment. The former is a historical question that has today become South Africa's most serious economic problem. The latter is of a more recent date, the combined product of trade union militancy and ill-judged labour legislation. From whatever angle the unemployment problem is approached, any serious enquiry is bound to arrive at these causal factors : unskilled labour and inflexible markets. Such is not only the finding of this particular study, but one supported by many independent conclusions and research projects.

For example, The Economist (December 13 1997:17) wrote the following on the subject of unemployment in South Africa:

Part of the problem is the heavy state-imposed cost to employers of hiring and firing, which has risen under the government's new labour laws. In addition the labour market is made sticky by an illiterate and unskilled workforce, which pushes up the cost of scarce skilled labour.

Taking a second example, a survey by the South African Institute of Race Relations (SAIRR) found two sets of major hindrances to the employment of less skilled labour in Gauteng Province - the economic heartland of the country. First :

In one context the characteristics of the labour market are completely dominant as a consideration; the difficulties and impediments in hiring more less-skilled labour. Virtually every [survey] respondent, black and white, identified problems in the field of labour relations, labour laws, trade union activity or the [poor] cost effectiveness of unskilled and semi-skilled labour (Schlemmer \& Levitz, $1998: 49$ ). 
These may be called impediments of a market-related nature. To them the SAIRR survey adds a second set of environment- or culture-related impediments, namely, low skills, high wages, high costs, low productivity and low motivation.

Seen through rose-tinted spectacles, the South African government's economic policy has been described as "fairly free-market economics" (TE, Dec. 71996 : 47). The macroeconomic strategy known as GEAR is often taken as sufficient proof of the government's commitment to a market-based economic system, no matter what the rest of its economic policy might be. If this is the essence of the South African economy today, what is the nature of its political counterpart? The question calls for a somewhat circuitous answer.

Before the final collapse of the USSR in 1991, the politics of the South African government-in-waiting (the ANC-SACP-Cosatu-alliance) closely resembled the Moscow version of communism, whose economic parallel was the system of planned (or "real") socialism. On the disintegration of the Soviet Union, however, the alliance became a political orphan. If the fall of sovietism caused the plan to be replaced by the market, does the metamorphosis of a commissar into a democrat logically follow? Not necessarily, for in today's world it is by no means uncommon to be an autocrat and a democrat at the same time.

This topic has been eloquently discussed by Fareed Zakaria ("The Rise of llliberal Democracy") in the American journal Foreign Affairs (Nov./Dec. 1997 : 1, 22-43)) from which the following précis has been taken :

\begin{abstract}
Around the world, democratically elected regimes are routinely ignoring limits on their power and depriving citizens of basic freedoms ... [thus] we see the rise of a disturbing phenomenon : illiberal democracy. It has been difficult to recognize because for the last century in the West, democracy - free and fair elections - has gone hand in hand with constitutional liberalism - the rule of law and basic human rights. But in the rest of the world, these two concepts are growing apart. Democracy without constitutional liberalism is producing centralized regimes, the erosion of liberty, ethnic competition, conflict and war.
\end{abstract}

This description fits the South African polity today almost perfectly. Moreover, it represents a political attitude that is very likely to beget a strongly authoritarian economic outlook too, thus resulting in an irrational and unstable political economy relation ("the interaction of political and economic variables"). The epitome of 
such a system, at the same time imperious and inefficient, was National Socialism in Germany (1933-45), which has also been described as an "economy without economics" (Neumann, 1963:211). Although Hitler never claimed to be a democrat, by today's standards he might plausibly have done so, for almost 90 per cent of the German and no less than 99.75 per cent of the Austrian electorate endorsed his most radical political measures (Kershaw, 1991:212,214). The Nazi economic system rested on control rather than nationalisation, coupled with the rejection of economic liberty and free markets.

South Africa seems to be moving in the same direction. The dismantling of civil liberties by the country's democratically elected government has been competently set out by Tony Leon in a paper called "The Death of the Rainbow Nation" (Internet http://dp.org.za). The counterpart of a schizoid polity ("illiberal democracy") is a dirigiste economy, as recently discussed in this Journal (vol. 21, 1997). Common to the loss of both political and economic freedom, is the government's guiding principle of "comparativeness" or "representativity", briefly put, the fallacy that the racial composition of the total population should also be reflected in most (or all?) conceivable subdivisions of society (e.g. tertiary education, national sports teams, public and private employment). The main economic disadvantage of comparativism is that it contradicts the principle of specialisation, on which all forms of productive activity are founded. Still in the economic context, the policy-induced distortions in the labour market, called "affirmative action", perversely aggravate the currently high unemployment in South Africa that was identified as the core problem of economic policy in this paper. As Leon points out, affirmative action is not associated with equality of opportunity but with equality of outcome, an impossible fiction not taken seriously anywhere in the world - except in South Africa today. Ironically enough, the racial bias of the Employment Equity Act resembles the previous government's labour legislation tumed upside down, for example, the equally misguided Physical Planning Act of 1967 required business firms to maintain a ratio of black to white employees of $2: 1$ (Tomlinson \& Addleson, 1987:38).

Given its past deep-rooted commitment to planned socialism, the present South African government has in fact had the market economy pretty well foisted on it by a major accident of history. This may have contributed to the misconception that it is somehow possible to retain the positive attributes of rival economic systems, while discarding their negative ones. But the institutions (e.g. property rights, decision-taking, incentives) that make up a particular economic system, are essentially of a complementary nature and, hence, basically indivisible. Nor is it possible to enjoy the advantages of the output markets, at the same time 
manipulating the input markets, particularly the labour market, according to the dictates of affirmative action. (The attempt to create such a spurious hybrid by force, eventually led to the destruction of the Yugoslav state.) Furthermore, complete disregard - or ignorance - of liberal values at times gives rise to breathtakingly outlandish policy proposals. For example, not since the days of Hitler and Stalin have innocent people been sentenced to forced labour as a matter of public policy. Yet the South African government under the leadership of the Minister of Health, seems bent on doing precisely that to university graduates. In the dark days of statutory racial segregation the American journal Business Week (Sept. $231985: 50$ ) wrote : "The economy is one of the few aspects of life in South Africa that transcend apartheid." Shocking as the thought may be, is a system that passes for democracy now undermining the South African economy as never before, and subjecting the nation to unknown internecine strife?

Finally, to answer the question put in the Introduction (political economy or virtual economics?), South Africa's policy-makers seem about to leave the real world of political economy to enter the illusory world of virtual economics instead, where a gigantic lie stands on a pin-point of truth. How can such an aberration happen?

Undying fidelity to an extinct politico-economic system (communism-socialism) is more than likely a big part of the explanation. Thus revolution is now called transformation (phase two), class struggle has become affirmative action and the classless society will be a politically correct one. None of this makes economic sense, as not only the breakdown of communism-socialism but South Africa's persistent unemployment rate show. Economics, like nature, does not proceed by leaps and bounds. Natura non facit saltum was the motto that Alfred Marshall chose for the title-page of his celebrated Principles of Economics, first published in 1890 and still widely read today.

\section{REFERENCES}

1. BACON, R. \& ELTIS, W. (1978). Britain's Economic Problem : Too Few Producers (2nd edn). London: Macmillan, p.35.

2. BARRO, R.J. (1991). "Economic Growth in a Cross-Section of Countries". Quarterly Journal of Economics, May 1991, pp. 408-43.

3. BLANCHARD, O. \& KATZ, L.F. (1997). "What We Know and Do Not Know About the Natural Rate of Unemployment". Journal of Economic Perspectives, Winter 1997, pp. 66-67. 
4. CENTRAL ECONOMIC ADVISORY SERVICE (1993). The Restructuring of the South African Economy : A Normative Model Approach. Pretoria, Government Printer.

5. GIDE, C. \& RIST, C. (1917). A History of Economic Doctrines. London : Harrap, p.252.

6. GORDON, R.J. (1997). "The Time-Varying NAIRU and its Implications for Economic Policy". Journal of Economic Perspectives, Winter 1997, pp. 2930

7. HALL, R.E. and Jones, C.I. (1996). The Productivity of Nations. National Bureau of Economic Research, Working Paper 5812, Cambridge Mass., p.33.

8. D. HOBART HOUGHTON (1967). The South African Economy (2nd edn). Cape Town : Oxford University Press, p. 165.

9. KAPSTEN, E.B. (1996). "Workers and the World Economy". Foreign Affairs, May/June 1996, pp. 16-37; and responses by : P. Krugman, R.Z. Lawrence, Foreign Affairs, July-August 1966, pp. 164-73.

10. KERSHAW, I. (1991). Hitler. London : Longman : 212, 214.

11. KRUGMAN, P. (1997). "Is Capitalism Too Productive?" Foreign Affairs, September/October 1997, pp. 79, 82.

12. MONDO 2000: A Users Guide to the New Edge. London: Thames \& Hudson, p.252.

13. NEUMANN, F. (1963). Behemoth. New York: Octagon Books, p. 211.

14. ROBINSON, J. (1962). Economic Philosophy. London: Watts, p.1.

15. ROMER, P.M. (1986). "Increasing Returns and Long-Run Growth", Journal of Political Economy, vol. 94, no. 5, pp. 1002-37.

16. SACHS, J. (1997). "The Limits of Convergence: Nature, Nurture and Growth". The Economist, June 14 1997, pp. 19-24.

17. SAMUELSON, P.A. \& Nordhaus, W.D. (1992). Economics (14th edn). New York: McGraw-Hill, p. 546.

18. SCHLEMMER, L. \& LEVITZ, C. (1998). Unemployment in South Africa. Johannesburg: SAIRR, p.49.

19. STIGLITZ, J. (1997). "Reflections on the Natural Rate Hypotheses". Journal of Economic Perspectives, Winter 1997, p.4.

20. TOMLINSON, R. \& ADDLESON, M. (eds.) (1987). Regional Restructuring under Apartheid. Johannesburg : Ravan : 38. 
21. TRUU, M.L. \& CONTOGIANNIS, E. (1996). Macroeconomics (2nd edn). Cape Town: Maskew Miller Longman, pp. 221-5.

22. TRUU, M.L. (1997). "Wanted: An Economic System for South Africa". South African Journal of Economic and Management Sciences, Volume 21, p.47.

23. TRUU, M.L. (1992). "Nationalization and Privatization", in Schrire, R. (ed.) Wealth or Poverty? Cape Town : Oxford University Press, p. 291.

24. WILSON, F. (1972). Labour in the South African Gold Mines. Cambridge University Press, p.1.

25. World Development Report. (1995): Workers in an Integrating World. New York : Oxford University Press, p.3.

Abbreviations : $A R$ - South African Reserve Bank Annual Report, $B W$ - Business Week, CEAS - Central Economic Advisory Service, FM - Financial Mail, FTS Financial Times Survey, GEAR - Growth, Employment and Redistribution, A Macro-Economic Growth Strategy, $P N$ - Pretoria News, $Q B$ - South African Reserve Bank Quarterly Bulletin, STBT - Sunday Times Business Times, $T E$ - The Economist, TEIU - The Economist Intelligence Unit, WDR - World Bank World Development Report. 